\title{
Role-Playing Games for Common Well-Being in High School - Notes from a Study Developed in Southern Brazil
}

\author{
Rafael Ramires Jaques and Cláudia Alquati Bisol
}

\begin{abstract}
As violence increases in Brazilian schools and the dropout rates grow, common well-being becomes a challenge. Several studies have been developed in order to understand these phenomena and find solutions to these problems. This paper begins with a brief contextualization of the current Brazilian situation and some challenges regarding relationships in Brazilian high schools. Suggesting that it may be possible to promote companionship and common well-being in the school environment through the use of games, this study also brings a report of two workshops held in an educational institution in southern Brazil in which Role-playing Game (RPG) was used for educational purposes. From this experience, it is possible to make some considerations about the use of this kind of game and its potential.
\end{abstract}

Index Terms-Education, common well-being, companionship, role-playing game.

\section{INTRODUCTION}

In a society that has been more and more confrontational, the school environment is suffering under the same circumstances. Brazilian education is going through a crisis [1] that has worsened due to recurrent problems of violence in different levels of society, including the daily lives of students and teachers [2].

Establishing positive relationships or simply "being together" in the classroom has become a challenge due to conflicts, disagreements, physical and verbal aggression that occur daily and this impacts student learning [3]. At the same time, there are statistics indicating that the number of students who are quitting school is increasing [1]. Is violence influencing the decision to drop out of school?

At this critical moment, in which the Minister of Education affirmed that Brazilian High School is a "disaster" [4], little by little the amount of research that seeks to investigate these phenomena increases.

This paper is based on the assumption that it may be possible to improve this situation through a project that seeks to support students, to strengthen ties, to reduce conflicts, and to increase acceptance of the different points of view that exist

Manuscript received October 20, 2018; revised April 14, 2019. This work was supported in part by CAPES (Coordenação de Aperfeiçoamento de Pessoal de Nível Superior - Brazil - PDSE 47/2017) and IFRS (Instituto Federal de Educação, Ciência e Tecnologia do Rio Grande do Sul - Brazil Process \#23360.000556/2017-69).

Rafael R. Jaques is with Instituto Federal de Educação, Ciência e Tecnologia do Rio Grande do Sul (IFRS), Campus Bento Gonçalves, Brazil (e-mail: rafael.jaques@bento.ifrs.edu.br).

Cláudia A. Bisol is with Universidade de Caxias do Sul (UCS), Brazil (e-mail: cabisol@ucs.br). in society.

To do so, we use one of the approaches that have been studied to try to promote common well-being and companionship in school: the use of games in the classroom [5]-[7]. This paper seeks to bring some notes about the use of a specific game (Role-playing Game) and, from the reports of some workshops that were carried out with high school students in southern Brazil, offers some suggestions on how to use this game in the school to try to increase integration and acceptance among students.

\section{LITERATURE REVIEW}

\section{A. High School in Brazil}

Two data points draw attention in the current Brazilian educational context: school violence and dropout. In Brazil, violence has been part of the daily life in schools. In a report published in 2016 [2], 42\% of the students interviewed stated that they had already suffered some physical or verbal aggression in school. According to high school students, the lack of acceptance turns into verbal, physical and psychological violence, implicating the entire school community [3].

A study reveals that there has been an increase in the rate of high school dropout, which, until 2014, had been falling gradually [1]. The same study brings references showing that students who have dropped out are more likely to be exposed to violence, which could worsen a situation that is already critical.

At the same time, it is known that in 2017 , only $59.2 \%$ of Brazilian youths up to 19 years completed high school [1]. Therefore, students are exposed to violence both in and out of school and this can be one of the causes of the conflicts that occur in classroom relationships.

In a context where a number of factors have contributed to the worsening of the situation (such as threats, robberies, thefts, bullying, etc.) [2], "being together" has been a constant challenge. To be in school, to be with others, represents being in diverse social relationships [8]. It is, at the same time, living the conflict.

This daily tension, despite having different roots, creates a scenario that opens the way to study how to mitigate the problem. The research that pointed out the rates of students who were victims of aggression in the school environment [2] offers suggestions on how to deal with the situation. One of them concerns the implementation of programs to promote companionship and common well-being. 
Thus, research has been conducted on the use of games in the classroom, seeking to verify if it is possible to increase the permanence of the students and to improve the human relations in the school [6], [9], [10].

\section{B. Games in Education}

Playing is a cultural element present in daily life. People play because they want to escape from the real world - they want to have fun [11]. The suspension of reality allowed by games and the experience of situations through the imaginary makes it possible to see games beyond entertainment [12].

Therefore, it is possible to find games in several contexts, including the pedagogical field. There are many studies that explore the use of games in education (i.e. [5]-[7], [9]-[10], [13], [14]). In general, these studies aim to understand how it is possible to teach something through the act of playing.

In this paper, however, the objective is not to propose the use of games to teach lessons, but to allow students to be together. To achieve that, the chosen game was the Role-playing Game (RPG). This is not the first time that the RPG is used for this purpose (as can be seen in [15], [16]), but this study attempts to offer new ways of thinking about the game in the classroom.

\section{Tabletop Role-Playing Games}

In a simple way, Role-playing Games (RPG) can be distinguished in two categories: electronic and tabletop. This study concerns the tabletop RPG, which is a spoken, collective, cooperative game with characters created by the players, in which fiction is produced [10], [17]. In general, RPGs are played around a table using only paper, pen, and dice. One of the players, called the Game Master (or Storyteller), is responsible for the progress of the game sessions and for the description of the events of the imaginary world. The other players interpret their characters, also verbally.

Players make an agreement about the setting in the beginning (such as the context where the story takes place and the abilities and limitations of the characters) and after that, the game session starts - it will be like an improvised theater [17]. The Game Master describes the scene and the settings, then the players assume the role of their characters describing their actions. Afterward, the Game Master describes the events unleashed from the actions of the players and the game follows this dynamic. RPGs differs from most of the other games (especially electronics) because it gives the players endless possibilities - whatever it is possible to imagine can be tried in game [10].

Because it is a cooperative game, RPGs have been investigated in several studies as a possible way to promote and support human relationships [10], [18]. Therefore, this work aims to point out some RPGs feature that can be used as a pedagogical tool based on the experiences of its use in the educational environment.

\section{MethodOLOGY}

This study presents two workshops that took place in the years of 2012 and 2017 in the IFRS (Education, Science and
Technology Federal Institute of Rio Grande do Sul), an educational and research institution located in the state of Rio Grande do Sul (southern Brazil), which receives students from high to graduate school.

In 2012, an RPG workshop was held in which 33 high school students (ages 14-17) participated in 7 groups of up to 5 participants (Workshop 1). The teacher responsible for the workshops was the Game Master and the students were the regular players. The group creation was initially made according to the participants' choice. Students were allocated randomly when they did not want to or could not choose the groups.

Based on studies that pointed out RPGs as a game capable of supporting the development of social skills and interaction [19], [20], the possibility of taking it into the classroom was first thought. Thus, with this purpose, Workshop 1 was held, and lasted 6 weeks, with weekly one-hour meetings for each of the 7 groups.

Another workshop was held in 2017, aimed to the general public, both internal and external to the institution (Workshop 2 ). The purpose of this second workshop was to publicize Role-playing Game as a cultural, leisure and potentially educational element. Eleven people participated in this workshop (students from different educational institutions of the city, aged between 16 and 30 years), attending a presentation about the RPG and its possible uses for leisure and education. Participants were then divided into two groups and were able to experience the game in hands-on sessions where everyone took turns in the roles of player and Game Master. The whole workshop lasted approximately 4 hours.

\section{IV. “BEING TOGETHER” DURING THE WORKSHOPS}

From the work done with the participants of the two workshops and with the feedback obtained, it is possible to make some observations regarding the use of games in the classroom and the relationships in the school environment.

Some groups from Workshop 1 were formed by affinity between participants, others were created randomly. In both cases, there was cooperation in the game. It was also possible to see that there was integration among the students, especially related to those who were participating in groups in which, although they knew their classmates, they did not have a close bond with them.

In addition, it was possible to observe that the students began to share other moments together, outside the workshops, talking about the game and even scheduling games sessions on their own.

Another characteristic that drew attention throughout the workshops concerns some students who appeared to be shy at the beginning of the process. Over time, they were more communicative, participating in the group discussions, something they initially avoided.

None of the students missed the meetings, appearing to be very interested in the game. When the workshops ended, some of them requested the extension of the period, but this was not possible. Thereupon, they chose to continue playing, creating their own RPG meetings, in and out of school, demonstrating an integration that went beyond the educational environment. 
In Workshop 2, participants expressed their interest in using RPG with pedagogical purposes. Some of them already knew the game and attended the workshop to find ways to apply it in the classroom. The participants who wanted to know the game, after trying it, considered the possibility of applying it in school. They also pointed out the alternation of characters as positive in the workshop, helping to have different experiences of role-playing.

After the Workshop 2, one of the participants organized some RPG events in a local cafeteria, gathering around 30 people in each event, which seems to have promoted social integration.

In both workshops, the creation of random groups allowed interactions between people who, until then, did not know each other or did not relate much. Even in this context, the players managed to work together as a team. This is a very interesting attribute of cultural activities and, based on this experience, it was possible to verify that the RPG also provides moments of integration.

\section{RPGS IN THE ClassRoOM: PeDAGOGICAL CONSIDERATIONS}

From the perceptions about the activities developed in the workshops, it is possible to point out some topics regarding the use of RPG in classes in order to promote companionship among students.

In general, games used in the classroom are designed for pedagogical purposes or transformed to fulfill some pedagogical role [21]. However, as mentioned before, RPG is a type of game that needs little or no adaptation when it comes to working towards integration among students. Cooperation and teamwork are part of the essence of the Role-playing Game and this, combined with the fact that there is no competition, provides a moment of integration with less conflict.

The cooperative situations made available by the game can help players to understand and experience real-life moments through role-playing. In this context, practicing cooperation and understanding more about interdependence in society is part of the exercise of playing RPG. This kind of game can be used as an educational technology that provides new ways of socializing in the educational environment. The game can thus bring to the classroom new forms of dialogue, teamwork, and collaboration [22].

To provide access to play, entertainment, and fun through non-competitive games (where the goal is not to defeat the other players) may encourage students to use their skills not only for their own benefit but also to bring gain to those around them. Thus, exercising the dialogue to find the best solutions to the challenges proposed is also to exercise their social skills. In the staging, it is possible to understand that all actions have consequences, which can help develop a sense of responsibility [23].

According to the abilities and personality traits of each individual, social interaction and argumentation become more explored resources instead of always searching for conflict. It is common for players, especially beginners, to try using superpowers to find the solution of problems, avoiding dialogue and moving directly to a quick solution [23]. As they become more experienced, players tend to decrease the frequency with which they use "brute force" and to appreciate social interaction and dialogue, discussing with their peers' strategies for solving problems [23].

Discussing with other players, relating to other people, living the difference that exists between individuals, may promote common well-being. It is also worth mentioning the possible benefits that can come from the creation of random groups for playing. Students often prefer to play with classmates whom they have more affinity, and this is not a problem. However, allowing a closer contact with other people can lead to the creation of new bonds.

Likewise, allowing students to take turns in the roles of player and storyteller can lead to different ways to approach the same situation. It is also possible to remain in the role of player, only changing characters. This alternation allows the interpretation of new roles, bringing new perspectives and, in a certain way, experimenting what it is like to be in the place of the other, assuming new characteristics.

This way of being in relation to the other, of being in relation to the differences, has an important role because it can lead to less conflictive relations in the school environment. These workshops with the RPG in the classroom led to the formalization of a research about the potentialities that the RPG has of creating relationships between the students [10]. Under those circumstances, it is possible to affirm that the Role-playing Game can be a pedagogical tool of integration in the classroom, which opens the possibility for many studies to be realized.

\section{CONCLUSION}

Brazilian reality presents itself with growing violence. Schools are part of this scenario. In a conflict-ridden society, bringing people together and strengthening the bonds of companionship can help reduce strife.

Bringing the game to the school environment may, in addition to helping keep students' interest in school, teach values such as respect and acceptance, something that, when not present, may trigger violence.

This study aimed to better understand how it is possible to use the game in the classroom to provide different forms of social integration among students. Throughout the process, it was possible to note some insights on how students behaved during the period.

Students of different ages were followed in two separate workshops. High school students who participated in Workshop 1 already knew each other. Workshop 2 was opened to the general public so there was no previous interaction. Following the students during the workshops allowed us to identify some behaviors that seem to be promising, in the sense of advancing the study regarding the use of Role-playing Games as a common well-being educational tool.

In Workshop 1, in which players were followed for a longer period, it was possible to notice the strengthening of ties. The way students dedicated themselves to the game, getting together to discuss game strategies, exchanging information 
about their characters and even scheduling game sessions outside the school environment, provides good clues towards future work concerning the use of RPGs. In Workshop 2, however, there was no way to verify this because of its short duration. Still, as with Workshop 1, there were scheduling of new game matches for the future, which may reveal some social integration, even among people who did not know each other.

In both Workshops, it was noticeable that there was creation of bonds. People who came from different contexts of life, with different points of view, met, played and cooperated. These relaxed and friendly interactions between the players allows us to think about future research, seeking to identify whether there is indeed an increase in integration and acceptance among students.

While our reality proves itself challenging, there is a growing need to find ways to enrich the common well-being. In RPGs, the way players are placed face to face and interact, even when playing characters, can be considered "being in relation to the other". Although RPG is role-playing, "being together" is not [10]. The moments of integration provided by the game can be valuable in the school context and result in a sense of collaboration towards common well-being.

In the workshops held in southern Brazilian schools, the students were very interested in the game and it was possible to notice that the socialization that began as a school activity eventually surpassed the walls of the classroom to the external context.

From this study, new ways of using the RPG in the school context may be formalized, seeking student's integration, acceptance of differences and respect between individuals. Proceeding with the studies may give more strength to games in the classroom so that pedagogical activities may continue to fulfill their objective: to transform society.

\section{ACKNOWLEDGMENT}

We would like to thank the students who participated in the reported workshops, without whom it would not have been possible to make the observations that were presented in this paper.

\section{REFERENCES}

[1] Anuário Brasileiro da Educação Básica. (2018). [Online]. Available: https://www.todospelaeducacao.org.br/conteudo/anuario-brasileiro-da -educacao-basica-2018-disponivel-download

[2] M. Abramovay, M.G. Castro, A. P. Silva, and L. Cerqueira, Diagnóstico Participativo das Violências nas Escolas: Falam os Jovens, 1st ed. Rio de Janeiro, Brazil: FLACSO, 2016, ch. 2-3, pp. 20-88.

[3] M. R. Esteves, "Violência no contexto escolar sob a óptica de alunos do ensino médio," Ph.D. dissertation, Escola de Enfermagem de Ribeirão Preto, University of São Paulo, São Paulo, Brazil, 2015.

[4] P. Aguiar, "'Ensino médio brasileiro é um desastre', diz ministro da Educação," R7 Notícias, 2018

[5] R. S. Siegler and G. B. Ramani, "Playing linear numerical board games promotes low-income children's numerical development," Developmental Science, vol. 11, no. 5, pp. 655-661, September 2008.

[6] H. Tüzün, M. Yılmaz-Soylu, T. Karakus, Y. Inal, and G. Kızılkaya, "The effects of computer games on primary school students' achievement and motivation in geography learning," Computers \& Education, vol. 52, no. 1, pp. 68-77, January 2009.

[7] N. Whitton, Learning With Digital Games, 1st ed. New York: Routledge, 2010.
[8] C. Skliar, "La pronunciación de la diferencia entre lo filosófico, lo pedagógico y lo literario," Pro-Posições, vol. 26, no. 1, pp. 29-47, January/April 2015.

[9] P. Escudeiro and C. V. de Carvalho, "Game-based language learning," International Journal of Information and Education Technology, vol. 3, no. 6, pp. 643-647, December 2013.

[10] R. Jaques, "Educação e linguagem: as situações enunciativas do role-playing game (RPG) como ferramenta pedagógica de constituição da alteridade," M.S. thesis, Centro de Ciências Humanas e da Educação, University of Caxias do Sul, Brazil, 2016.

[11] J. Huizinga, Homo Ludens, 1st ed. London: Routledge, 1949.

[12] G. Brougère, Jeu et Éducation, 11st ed. Paris: L'Harmattan, 2006.

[13] K. Peter and V. Banciu, "Game using in the language education activities of children with mild and moderate mental disabilities," International Journal of Information and Education Technology, vol. 3, no. 3, pp. 393-396, June 2013.

[14] D. Ding, C. Guan, and Y. Yu, "Game-based learning in tertiary education: A new learning experience for the generation Z," International Journal of Information and Education Technology, vol. 7, no. 2, pp. 148-152, February 2017.

[15] W. Hawkes-Robinson. Role-playing games used as educational and therapeutic tools for youth and adults. [Online]. Available: https://www.researchgate.net/publication/237074784_Role-playing_ Games_Used_as_Educational_and_Therapeutic_Tools_for_Youth_a nd_Adults

[16] R. S. Fujii, "O RPG como Ferramenta de Ensino: as contribuições do RPG para a argumentação no ensino de Biologia," Contexto \& Educação, vol. 26, no. 86, July/December 2011.

[17] D. Mackay, The Fantasy Role-playing Game: A New Performing Art, 1st ed. Jefferson, North Carolina: McFarland, 2001.

[18] M. A. P. Pool, "Desafios educacionais criativos associados às práticas docentes: estudo de caso considerando RPG educacional," Ph.D. dissertation, Pontifícia Universidade Católica do Rio Grande do Sul, Porto Alegre, Brazil, 2017.

[19] P. N. Almeida, Educação lúdica: técnicas e jogos pedagógicos, 11. ed. São Paulo, Brazil: Loyola, 2003.

[20] M. L. Borralho and A. M. F. Viegas. Para uma Escola com Masmorras e Dragões: as estratégias do jogo de R.P.G. na sala de aula. [Online]. Available: http://hdl.handle.net/10216/23037s

[21] L. D. Costa, O Que Os Jogos De Entretenimento Tem Que Os Educativos Não Tem. 7 Princípios Para Projetar Jogos, 1. ed. São Paulo, Brazil: 2AB, 2010.

[22] M. V. Silva, "O Jogo de Papéis (RPG) Como Tecnologia Educacional e o Processo de Aprendizagem no Ensino Médio," Congresso Nacional de Educação (EDUCERE). 2009 Anais eletrônicos..., 2009, pp. 6505-6517.

[23] M. S. Rocha, "RPG: Jogo e conhecimento - o role playing game como mobilizador das esferas do conhecimento," M.S. thesis, Faculdade de Ciências Humanas, Universidade Metodista de Piracicaba, Brazil, 2006.

Copyright $@ 2019$ by the authors. This is an open access article distributed under the Creative Commons Attribution License which permits unrestricted use, distribution, and reproduction in any medium, provided the original work is properly cited (CC BY 4.0).

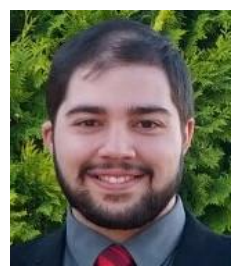

Rafael Ramires Jaques is a professor at the Education, Science and Technology Federal Institute of Rio Grande do Sul (IFRS), Brazil, since 2011. He obtained his master's degree in education in 2016 at the University of Caxias do Sul (UCS), Brazil, and is studying in doctoral course at the same university. His main research subjects are gamification, alterity, and games in education.

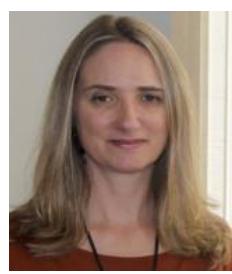

Cláudia Alquati Bisol is a professor at the University of Caxias do Sul (UCS), Brazil, since 2000. She obtained her master's degree in psychology in 1999 and her Ph.D. in psychology in 2008, both in the Federal University of Rio Grande do Sul (UFRGS), Brazil. Her research interests include special education, disabilities and special needs, psychology, and psychoanalysis. 